\title{
Variation in ultrasonic frequency and time as pre-treatments to air-drying of carrot
}

\author{
Ernest Ekow Abano, ${ }^{1}$ Livingston Kobina Sam-Amoah, ${ }^{1}$ Ato Bart-Plange ${ }^{2}$ \\ ${ }^{1}$ Department of Agricultural Engineering, University of Cape Coast, Cape Coast, Ghana; \\ 2Department of Agricultural Engineering, Kwame Nkrumah University of Science and Technology, \\ Kumasi, Ghana
}

\begin{abstract}
Vegetable drying is an alternative method to curb post harvest decay of vegetables and a process to produce dried vegetables, which can be directly consumed or used as ingredients for the preparation of soups, stews, baby foods, cakes, puddings, and many other foods. In this study, the effect of ultrasound frequency and sonication time as pre-treatment prior to air drying at $70^{\circ} \mathrm{C}$ at an air velocity of $0.5 \mathrm{~m} / \mathrm{s}$, on carrot drying kinetics, flavour, colour, and non-enzymatic browning was investigated using a 3-level factorial response surface method. The result showed that an increase in sonication frequency and time did not significantly increase moisture diffusivity but in comparison with the control, water diffusivity increased after ultrasound application and the overall drying time was reduced. Application of the ultrasound pre-treatment in distilled water resulted in water gain and sugar loss, indicating that the ultrasonic pre-treatment can be an important step to produce low sugar content dried products. The brightness and redness to yellowness values of the ultrasonically pre-treated dried carrots were better than those without ultrasound application. In comparison with the flavour of the control, the ultrasound pre-treated samples recorded higher flavour response signals, indicating that the application of ultrasound improved the flavour of the dried carrot. The variation in sonication frequency and time did not significantly affect the non-enzymatic browning index of the dried products but were better than the control.
\end{abstract}

\footnotetext{
Correspondence: Ernest Ekow Abano, Department of Agricultural Engineering, University of Cape Coast, Cape Coast, Ghana.

E-mail: ekowabano@yahoo.com
}

Key words: carrots, ultrasound, drying, flavour, colour, non-enzymatic browning.

Received for publication: 11 August 2012.

Accepted for publication: 15 January 2013.

(C) Copyright E.E. Abano et al., 2012

Licensee PAGEPress, Italy

Journal of Agricultural Engineering 2012; XLIII:e23

doi:10.4081/jae.2012.e23

This article is distributed under the terms of the Creative Commons Attribution Noncommercial License (by-nc 3.0) which permits any noncommercial use, distribution, and reproduction in any medium, provided the original author(s) and source are credited.

\section{Introduction}

Carrot (Daucus carota subsp. Sativus) is a root vegetable, which originated in the Indo-European area. Production of carrot and turnip in 2010 was estimated to be 35 million tonnes (FAO, 2010). With 15.899078 million tons, China was by far the largest producer and accounted for over $45.2 \%$ of the global output, followed by the USA (1.32437 million tons), Ubekistan (1.107 million tonnes), Poland (0.814932 million tonnes), and the United Kingdom (0.7479 million tons). The crop is a good source of vitamin C, vitamin B6, folate, pantothenic acid, iron, potassium and copper, and a very good source of dietary fibre, vitamin A (which enhances vision), vitamin K, and manganese.

The relatively high moisture content of carrot makes it a highly perishable crop and it deteriorates quickly at postharvest. Therefore, it is necessary to apply appropriate postharvest technology to prolong its shelf life. Drying is among the most popular methods used to produce several dried vegetables which can be consumed directly or used as ingredients for preparation of soups, stews, baby foods, cakes, puddings, and many other foods (Azoubel et al., 2010; Fernandes et al., 2008a, 2008b; Nguyen and Price, 2007; Karim and Hawlader, 2005). Nonetheless, conventional hot air drying can cause excessive quality deteriorations to the flavour, colour composition, vitamins, and essential amino acids of the final product (Mujumdar and Menon, 1995). The simultaneous heat and mass transfer process accompanied by phase change makes conventional hot air drying an energy intensive and consequently expensive process. Hence, a pre-treatment can be applied to reduce the initial water content or to modify the vegetable tissue structures so that air drying can become faster (Fernandes and Rodrigues, 2007). Among with the most reported pre-treatment technique used prior to drying, osmotic dehydration is common (Antonio et al., 2008; Pani et al., 2008; Lombard et al., 2008, Fernades et al., 2008b; Azoubel et al., 2009). However, among the emerging new technologies, ultrasound-assisted drying is very promising because the process can be carried out at a low temperature, which reduces the probability of food degradation (Mason, 1998) and permits the removal of moisture content from solids without producing a liquid phase change (Azoubel et al., 2010). Ultrasound applications in the food industry are on the increase as new uses are being studied (Fernandes et al., 2008a, 2008b).

The ultrasonic pre-treatment involves the immersion of the vegetables in water or in a hypertonic aqueous solution to which ultrasound is applied. In solid materials, ultrasound waves generate alternative compressions and expansion, and consequently produce a spongy effect similar to that observed when a sponge is squeezed and released repeatedly (De la Fuente et al., 2006). The spongy effect causes the ejection of liquid from the inner part to the surface of the vegetables and the entry of fluid from the outside. Muralidhara et al. (1985) reported that the forces involved in this mechanism can exceed the 
surface tension, which maintains the water molecules inside the capillaries of the material, setting up microscopic channels that reduce the diffusion boundary layer, and thus making it easier to exchange matter. Therefore, ultrasound application in solid materials changes the viscosity and surface tension, and cause solid structural deformation (Cárcel et al., 2011). Although some works report the study of ultrasound pre-treatment on drying (Fernandes and Rodrigues, 2007; Fernandes et al., 2008a, 2008b; Azoubel et al., 2010), there are no reports on variation of ultrasound frequencies as a pre-treatment prior to drying in the scientific literature.

The objective of this study was to investigate the variation of ultrasound frequency and time as pre-treatments and its effect on the drying kinetics, colour, flavour, and non-enzymatic browning of carrot.

\section{Materials and methods}

\section{Materials}

Fresh carrots were obtained in the local market of Zhenjiang, China, at a stage of ripeness ideal for processing. The carrots were washed with drinking water and machine sliced to $10 \mathrm{~mm}$ thickness. These were manually sliced into $10 \mathrm{~mm}$ cubes and kept in the refrigerator at $4^{\circ} \mathrm{C}$ until use. The initial moisture content was determined gravimetrically by heating $5 \mathrm{~g}$ of the samples at $105^{\circ} \mathrm{C}$ for $24 \mathrm{~h}$. The initial total soluble solid (Brix) was determined by refractometry to be $8.67^{\circ}$ Brix.

\section{Experimental design}

A 3-level factorial response surface methodology was used to design the experiment. The effect of two factors was used: ultrasound frequency (range 24-40 kHz) and sonication time (range 10-60 min).

\section{Ultrasound pre-treatment}

An experimental set consisting of carrot cubes was immersed in distilled water and subjected to ultrasonic waves at frequencies of 24,32 , and $40 \mathrm{kHz}$ for 10, 35 and $60 \mathrm{~min}$. The accuracy of the ultrasonic frequency was $\pm 1 \mathrm{kHz}$. These pre-treatment frequencies and times were chosen based on industrial practice. The water to fruit ratio was maintained at 4:1 on the basis of weight.

The ultrasonic pre-treatments were carried out separately in an online laboratory scale ultrasonic bath system (Jiangsu University model no. 20084798) having five sweep frequencies in the range of 22$68 \mathrm{kHz}$ at maximum power of $18 \mathrm{~W}$. The parameters of the ultrasound pre-treatment chosen for the experiment were $300 \mathrm{~ms}$ for period, $10 \mathrm{~s}$ for ultrasound working time, and $3 \mathrm{~s}$ for ultrasound rest time. The experiment was carried out under ambient temperature of $29^{\circ} \mathrm{C}$ in an ultrasonic bath without mechanical agitation.

After the samples were removed from the water solution, they were drained and blotted with absorbent paper to remove excess water. The weight was determined and samples were subjected to drying. The temperature was measured before and after the runs and the increase in temperature during the runs was within $2^{\circ} \mathrm{C}$. Each run was duplicated for the drying experiment. At the end of the ultrasound pre-treatment, samples were taken to determine its total soluble solids by refractometry. This step was undertaken to quantify the amount of sugar that the carrots lose by mass transfer to the water medium.

The weight and moisture content of the samples, and the sugar content of the carrot cubes were used to determine the water loss (WL) and solid gain (SG), following equations 1 and 2.

$$
\begin{aligned}
& W L(\%)=\frac{w_{i} M_{i}-w_{f} M_{f}}{w_{i}} \times 100 \\
& S G(\%)=\frac{w_{f} X_{f}-w_{i} x_{i}}{w_{i}} \times 100
\end{aligned}
$$

where:

$M_{i}$ and $M_{f}$ are the initial and final moisture content on a wet basis (g water/g);

$w_{i}$ and $w_{f}$ are the initial and final vegetable mass (g);

$X_{i}$ and $X_{f}$ are the initial and final carrot soluble solid content (g solid/g).

\section{Air-drying}

After removal from the ultrasonic bath, the samples were drained, blotted with absorbent paper to remove excess water solution and transferred to a forced air dryer (Jiangsu University) set at $70^{\circ} \mathrm{C}$ and air velocity of $0.5 \mathrm{~m} / \mathrm{s}$. The schematic diagram of the dryer used in this experiment is shown in Figure 1. This temperature was chosen based on industrial practices and optimisation studies carried out previously (Abano and Sam-Amoah, 2011). Carrot cubes (50 g) were placed in the dryer sample holder for air-drying. During drying, the samples were weighed every $15 \mathrm{~min}$ in the first $2 \mathrm{~h}$ and later at 30 -min intervals until the dynamic equilibrium between the sample moisture content and drying air humidity was reached, i.e. when the sample weight became constant. The data were used to compute the water diffusivity of carrot during air-drying at $70^{\circ} \mathrm{C}$ according to Fick's Law of diffusion. The equation used for the falling rate period of the drying process was based on the simplification of Fick's second law considering long processing period (Perry and Green, 1999). The coefficient of moisture diffusivity was adjusted using Eq. (3) with a parameter estimation procedure based on least squares:

$$
\frac{\partial M}{\partial t}=-\frac{2 \pi}{L^{2}} D_{\mathrm{eff}}\left(M-M_{e}\right)
$$

where:

$D_{\text {eff }}$ is the effective water diffusivity $\left(\mathrm{m}^{2} / \mathrm{s}\right)$;

$M$ is the moisture content ( $\mathrm{g} \mathrm{H}_{2} \mathrm{O} / \mathrm{g}$ dry matter);

$M_{\mathrm{e}}$ is the equilibrium moisture content ( $\mathrm{g} \mathrm{H}_{2} \mathrm{O} / \mathrm{g}$ dry matter);

$t$ is the time (s); and

$L$ is the thickness of the sample (m).

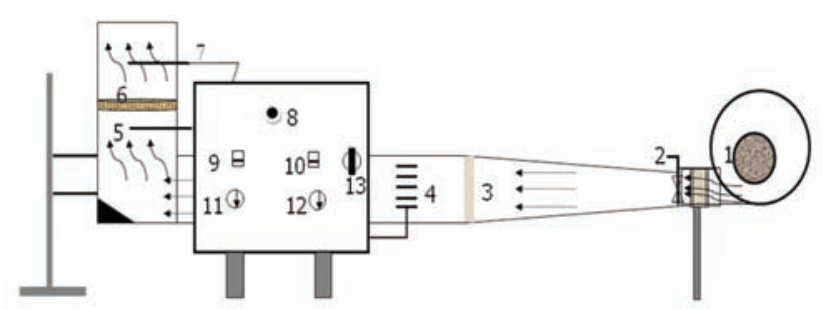

1. Air pump

2. Air flow meter

3. Air cleaner

4. Heater

6. Sample holder

7. Outlet temperature probe
5. Inlet temperature probe
8. Machine on off

9. Inlet temperature controller

10. Outlet temperature controller

11. Heater on off

12. Air circulation on off

13. Open lock machine control unit
Figure 1. The hot air dryer and associated units. 
The $\mathrm{D}_{\text {eff }}$ was obtained by fitting the experimental data to the Fick's diffusion model, using the non-linear estimation resources of SPSS 16.0 (SPSS Inc., Chicago, IL, USA). The thickness of either the fresh carrot or the ultrasonically pre-treated carrot was assumed as the initial dimension. The Page model (Page, 1949) (one of the most useful empirical models) was used to fit the experimental drying data. The Page equation is written according to the formula:

$$
\frac{M-M_{e}}{M_{0}-M_{e}}=M R=\exp \left(-k t^{n}\right)
$$

where:

$M$ is moisture content at time t;

$M o$ is the initial moisture content;

$M e$ is the equilibrium moisture content (all in $\mathrm{g}_{2} \mathrm{O} / \mathrm{g}$ dry matter);

$k$ is the drying rate constant in $\mathrm{min}^{-1}$;

$n$ is the dimensionless model parameter;

$t$ is the process time in min.

The goodness of fit of the model was characterised by the residual sum of squares (RSS), root mean square error (RMSE), reduced chisquare $\left(\chi^{2}\right)$, and the determination coefficient $R^{2}$, according to the equations below.

$$
\begin{aligned}
& R S S=\sum_{i=1}^{N}\left(M R_{\text {expt }, i}-M R_{\text {pred }, i}\right) \\
& R M S E=\sqrt{\frac{1}{N} \sum_{i=1}^{N}\left(M R_{\text {expt }, i}-M R_{p r e d, i}\right)^{2}} \\
& \chi^{2}=\frac{\sum_{i=1}^{N}\left(M R_{\text {expt }, i}-M R_{p r e d, i}\right)^{2}}{N-z}
\end{aligned}
$$

where:

$M R_{\text {expt,i }}$ and $M R_{\text {pred,i }}$ are the experimental and simulated dimensionless moisture ratio $(M R)$ respectively;

$i$ is the experimental observation in a given run for a total of $\mathrm{N}$ number of observations; and

$z$ is the number of model parameters ( 2 in the Page model).

The drying rate constants $(\mathrm{k})$ and dimensionless model parameter in the Page equation (n) were determined with nonlinear regression of SPSS 16.0 (SPSS Inc.).

\section{Colour measurements}

The colour of the fresh and dried tomato slices was measured in Hunter parameters with an automatic colour difference meter (DC-P3, Beijing, China). The calibration is standardised by placing the tip of the measuring heat flux against the surface of the white and black calibration plates. After standardisation, three random readings were recorded; the colour brightness coordinates $(L)$ measures the whiteness value of a colour and ranges from black (0) to white (100). The chromaticity coordinates i) measures the red when positive and green when negative, and the chromaticity coordinate ii) measures yellow when positive and blue when negative and both range from -60 to +60 .

\section{Flavour measurement}

The electronic nose system for agricultural products consisting of nine sensitive tin dioxide semiconductor sensors was used to monitor the flavour of the fresh and dried carrot. The instrument was previously described by (Xiaobo and Jiewen, 2008). Three and a half (3.5) grams of the fresh and reconstituted dried samples were sealed in the concen- tration chamber and incubated at a temperature of $27.0 \pm 0.09^{\circ} \mathrm{C}$. Thereafter, the samples were left to sit to enable the volatilisation of the flavour compounds into the headspace and were then pumped into the sensor chamber at a constant flow rate of $150 \mathrm{~mL} / \mathrm{min}$. The sensor response pattern signal was measured using pattern recognition algorithms controlled by a commercial acquisition board computer program PCL-816 (Advantech Inc., Taiwan, China). Sensor patterns were monitored until stable values were recorded by all nine sensors. Measurements were recorded in resistance changes experienced by the sensors when exposed to the flavour compounds.

\section{Non-enzymatic browning determination}

A modified method of Cernîşev (2010) was used to determine the browning index (BI) of the dried carrots. The degree of browning was evaluated as browning index measured as absorbance at $440 \mathrm{~nm}$ which was the wavelength for maximum elution of brown pigment in the dried products using $60 \%$ ethanol for extraction. Brown pigments were extracted from $0.8 \mathrm{~g}$ test portions from the dried carrot samples. Samples were ground into fine powder with a kitchen blender for $90 \mathrm{~s}$ after which $20 \mathrm{~mL}$ of ethanol $(60 \%, \mathrm{v} / \mathrm{v})$ was added and allowed to stand for $12 \mathrm{~h}$ after which the mixture was agitated and then filtered through 0.45 - $\mu \mathrm{m}$ nylon filter membrane. Browning index of filtrates was evaluated with a spectrophotometer (UNIC0 7200, Shanghai, China) against $60 \%$ ethanol as blank. All samples were extracted in duplicate.

\section{Statistical analysis}

Type III 3-level factorial analysis of variance (ANOVA) was carried out on the non-enzymatic browning index, colour brightness and ratio of redness to yellowness to ascertain the statistical significance of the terms in a second-order polynomial model. The Design Expert 8.0.7.1 statistical package (Stat-Ease Inc., USA, 2010) was used for the ANOVA at a probability of $5 \%$. The accuracy of the model to describe the response variables was diagnosed against the normal probability plots of the residuals, the predicted versus actual plots, and the coefficients of determination $\left(\mathrm{R}^{2}\right)$ values. The 3-D surface plots for two factors were generated for the various responses. Average values for triplicates were reported for all measurements with the exception of non-enzymatic browning where it was a duplicate.

Table 1. Water loss and solid gain after ultrasound pre-treatment.

\begin{tabular}{lcrc}
$\begin{array}{l}\text { Ultrasound } \\
\text { frequency }(\mathrm{kHz})\end{array}$ & $\begin{array}{c}\text { Sonication time } \\
(\mathrm{min})\end{array}$ & $\begin{array}{c}\text { WL } \\
(\%)\end{array}$ & $\begin{array}{c}\text { SG } \\
(\%)\end{array}$ \\
\hline \multirow{2}{*}{24} & 10 & -10.61 & -2.10 \\
& 35 & -9.82 & -2.21 \\
32 & 60 & -10.86 & -2.50 \\
& 10 & -10.03 & -2.40 \\
& 35 & -11.63 & -2.43 \\
40 & 60 & -10.66 & -2.41 \\
\hline & 10 & -9.96 & -2.49 \\
& 35 & -9.82 & -2.21 \\
& 60 & -10.86 & -2.10 \\
\hline
\end{tabular}

WL, water loss; SG, solid gain. 


\section{Results and discussion}

\section{Effect of ultrasonic pre-treatment on water loss and solid gain}

Table 1 presents the effect of ultrasonic pre-treatment on WL and SG. The results show that during ultrasound pre-treatment, the carrot cubes gained water and lost sugar. Fernandes and Rodrigues (2007), Fernandes et al. (2008), Azoubel et al. (2010) found similar results in the ultrasonic pre-treatment of banana cv. Navica, melon, and banana cv Pacovan, respectively. This was due to the concentration gradient that favours mass transfer of sugar from the carrot to the water medium and mass transfer of water to the carrots. Consequently, the moisture content of the fruit vegetable after ultrasonic treatment increased (3.78\% at $40 \mathrm{kHz}$ for $10 \mathrm{~min}$ )

\section{Drying}

The dimensionless moisture content was calculated and its change during drying up to the dynamic equilibrium point of the various pretreated and the control carrots is presented Figure 2. As expected, the moisture content decreased with drying time and followed an exponential decay. The mathematical modelling of the drying data using Eq. 4 for the fresh and pre-treated carrot at $70^{\circ} \mathrm{C}$ air temperature is also shown in Figure 3. Table 2 shows the Page's parameters for the carrot samples. It can be seen that the k parameter was fairly constant for the control and ultrasound pre-treated samples even though it was highest in the ultrasonic pre-treated samples at $32 \mathrm{kHz}$ for $10 \mathrm{~min}$. The $\mathrm{n}$ parameter was also higher in the ultrasound pre-treated samples than the control, except for the $32 \mathrm{kHz}$ for $60 \mathrm{~min}$ ultrasound pre-treated samples. Azoubel et al. (2010) dried bananas pre-treated at $24 \mathrm{kHz}$ for 10,20 , and 30 min at 50 and $70^{\circ} \mathrm{C}$ and found $\mathrm{k}$ parameter in the Page model to increase with air temperature (except the samples pre-treated for $30 \mathrm{~min}$ ). The same behaviour was found for $\mathrm{n}$ parameter (except for the 30 min ultrasound pre-treated samples). Azzouz et al. (2002) concluded that $n$ was a function of air velocity and initial moisture content, while $\mathrm{k}$ was a function of air temperature and initial moisture content of grapes.

The Page empirical model clearly fits the experimental data when compared with the results obtained using the diffusion model, with RSS less than 0.003 , RMSE less than 0.00913 , reduced $\chi^{2}$ less than

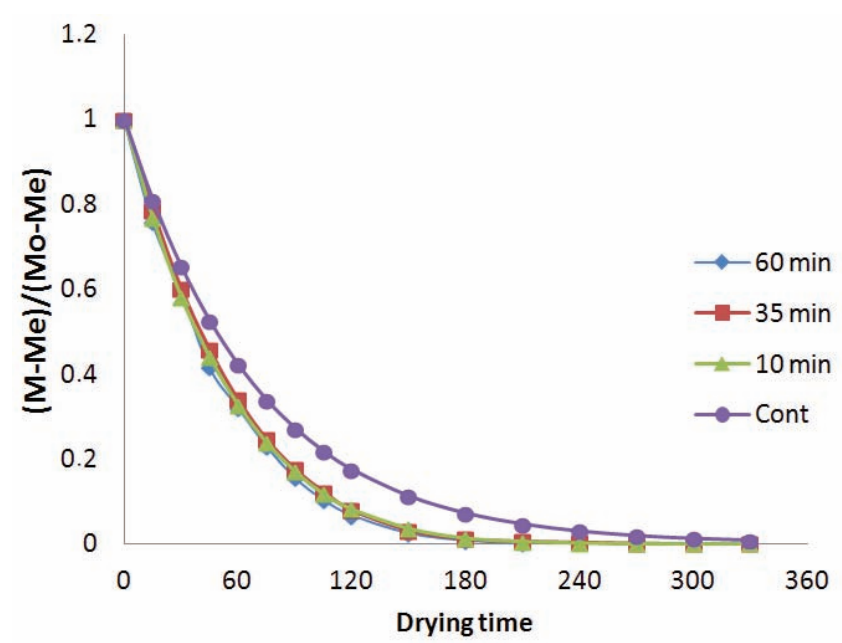

Figure 2. Dimensionless moisture ratio against drying time for the $40 \mathrm{kHz}$ ultrasound treated samples and the control.

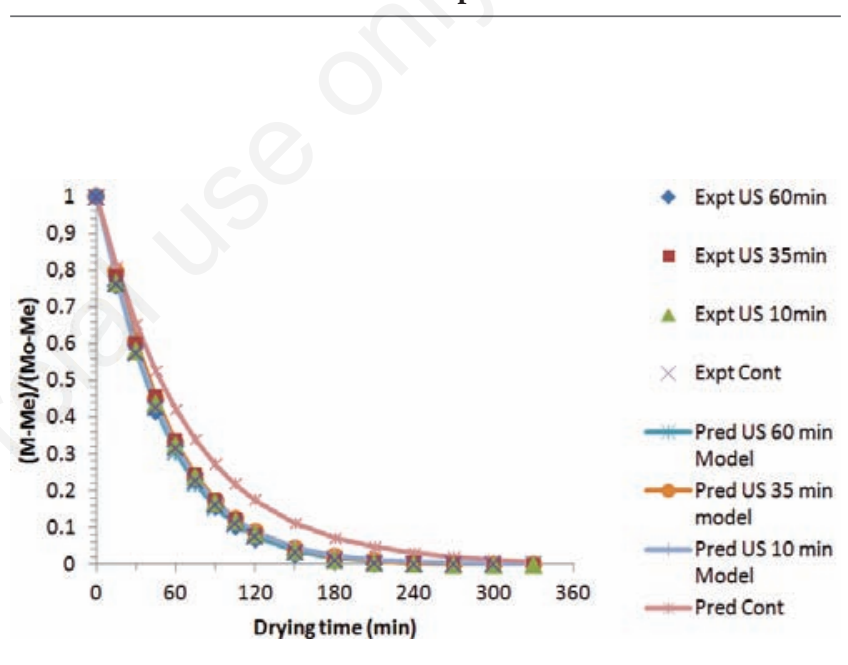

Figure 3. Experimental and predicted Page model for the control and the ultrasound (US) pre-treated carrot dried at $70^{\circ} \mathrm{C}$.

Table 2. Page's equation parameters and statistical results for the control and ultrasound pre-treated carrot dried at $70^{\circ} \mathrm{C}$.

\begin{tabular}{|c|c|c|c|c|c|c|c|}
\hline $\begin{array}{l}\text { Ultrasonic frequency } \\
(\mathrm{kHz})\end{array}$ & $\begin{array}{l}\text { Sonication time } \\
\text { (min) }\end{array}$ & k & n & $\mathbf{R}^{2}$ & RSS & RMSE & $\chi^{2}$ \\
\hline Control & - & 0.013 & 1.016 & 0.99788 & 0.003 & 0.0002143 & 0.01369 \\
\hline 24 & $\begin{array}{l}10 \\
35 \\
60\end{array}$ & $\begin{array}{l}0.012 \\
0.014 \\
0.014\end{array}$ & $\begin{array}{l}1.114 \\
1.098 \\
1.099\end{array}$ & $\begin{array}{c}0.99914 \\
0.9988 \\
1.000\end{array}$ & $\begin{array}{l}0.001 \\
0.001 \\
0.000\end{array}$ & $\begin{array}{c}0.00913 \\
1.4 \times 10^{-4} \\
0.0000\end{array}$ & $\begin{array}{c}1.0 \times 10^{-4} \\
0.01054 \\
0.000\end{array}$ \\
\hline 32 & $\begin{array}{l}10 \\
35 \\
60\end{array}$ & $\begin{array}{l}0.015 \\
0.013 \\
0.014\end{array}$ & $\begin{array}{l}1.1071 \\
1.107 \\
1.091\end{array}$ & $\begin{array}{c}1.000 \\
1.000 \\
0.9989\end{array}$ & $\begin{array}{l}0.000 \\
0.000 \\
0.001\end{array}$ & $\begin{array}{c}0.0000 \\
0.0000 \\
1.25 \times 10^{-4}\end{array}$ & $\begin{array}{l}0.000 \\
0.000 \\
0.010\end{array}$ \\
\hline 40 & $\begin{array}{l}10 \\
35 \\
60\end{array}$ & $\begin{array}{l}0.013 \\
0.010 \\
0.012\end{array}$ & $\begin{array}{l}1.094 \\
1.139 \\
1.123\end{array}$ & $\begin{array}{l}0.99930 \\
0.99932 \\
0.99829\end{array}$ & $\begin{array}{l}0.001 \\
0.001 \\
0.002\end{array}$ & $\begin{array}{c}7.143 \times 10^{-5} \\
7.143 \times 10^{-5} \\
2.0 \times 10^{-5}\end{array}$ & $\begin{array}{c}0.0079 \\
0.0079 \\
0.00107\end{array}$ \\
\hline
\end{tabular}

$\mathrm{k}$, dryin rate constant; $\mathrm{n}$, dimensionless model parameter; $\mathrm{R}^{2}$, determination coefficient; RSS, sum of squares; RMSE, root mean square error; $\chi^{2}$, reduced chi-square. 
0.010 , and $R^{2}$ greater than 0.998 . The high values of $\mathrm{R}^{2}$, and low values of RSS, RMSE, and $\chi^{2}$ recorded in Table 2 show that the experimental data are very similar to the simulated data for the Page model around logarithmic curves throughout the drying process. Previous authors have used this model to accurately simulate the drying of banana (Azoubel et al., 2010), kiwi (Simal et al., 2005), and tomatoes (Abano et al., 2011), among others. The measured and simulated graph shown in Figure 4 indicates good prediction agreement between the experimental and simulated values of dimensionless moisture content data.

Fick's parameters for the control and pre-treated carrot are shown in Table 3. The effective coefficient of diffusivities of water calculated using the dimensionless moisture ratio (Eq. 3) were higher for the ultrasound pre-treated samples but the effect may not be so great with temperatures above $70^{\circ} \mathrm{C}$. This is consistent with the observations of Fuente-Blanco et al. (2006) that the ultrasonic pre-treatment affects fruit vegetable tissue, making it easier for the water to diffuse during air-drying. Fernandes et al. (2008b) studied the cell structure of melon after ultrasonic pre-treatment using microscopic light and observed that this phenomenon may happen due to the process of formation of micro-channels when ultrasound is applied. Water could use the microscopic channels as an easier pathway to diffuse toward the surface of the fruit vegetable, contributing to the higher values of moisture diffusivity in ultrasound pre-treated samples.

Quantitatively, the increasing moisture diffusivity due to the appli-

Table 3. Fick's equation parameters and statistical results for control and ultrasonic pre-treated carrot dried at $70^{\circ} \mathrm{C}$.

\begin{tabular}{lccc}
$\begin{array}{l}\text { Ultrasonic } \\
\text { frequency }(\mathrm{kHz})\end{array}$ & $\begin{array}{c}\text { Sonication } \\
\text { time } \\
(\mathrm{min})\end{array}$ & $\begin{array}{c}\text { Deff } \\
\left(\times 10^{-9} \mathrm{~m}^{2} / \mathrm{s}\right)\end{array}$ & \\
Control & - & 2.25 & 0.9891 \\
24 & 10 & 4.68 & 0.9763 \\
& 35 & 4.10 & 0.9848 \\
& 60 & 4.58 & 0.9937 \\
\hline 32 & 10 & 4.00 & 0.9914 \\
& 35 & 4.49 & 0.9902 \\
40 & 60 & 4.37 & 0.9771 \\
& 10 & 4.81 & 0.9879 \\
& 35 & 4.31 & 0.9871 \\
& 60 & 4.51 & 0.9758 \\
\hline
\end{tabular}

Deff, effective moisture diffusivity; $\mathrm{R}^{2}$, determination coefficient.

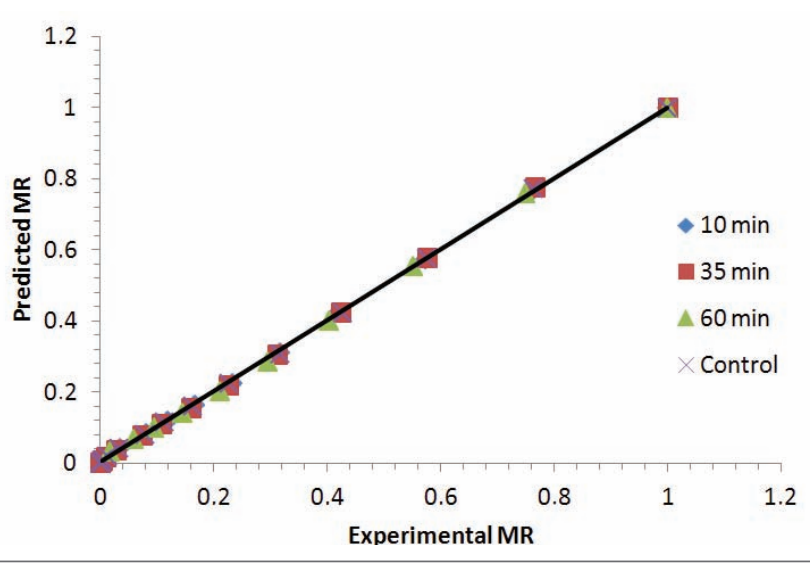

Figure 4. Predicted and experimental dimensionless moisture ratio (MR) for the Page model for $40 \mathrm{kHz}$ ultrasound pre-treated and control dried carrot at $70^{\circ} \mathrm{C}$. cation of ultrasound has great significance during the air drying process. For instance, if carrots are dried to a final moisture of $25 \%$ wet basis (33\% dry basis), which is the maximum moisture content value allowed for most dried fruits and vegetables, it will take 256 min to dry the samples without ultrasound at $70^{\circ} \mathrm{C}$, while by subjecting the carrots cubes to $32 \mathrm{kHz}$ ultrasound pre-treatment, in distilled water for 10,35 , and $60 \mathrm{~min}$, the drying times will be reduced to $178 \mathrm{~min}(30.47 \%), 149$ $\min (41.79 \%)$, and $141 \mathrm{~min}$ (44.92\%), respectively.

This will optimise processing time, reducing drying time to a minimum, reducing costs, and ultimately increasing overall productivity, as observed by Jambrak et al. (2007), Fernandes and Rodrigues (2007), Fernandes et al. (2008a, 2008b, 2009) and Azoubel et al. (2010) for ultrasonic assisted drying of button mushrooms, Brussels sprouts, cauliflower, pineapples, melons, and bananas. The moisture diffusivity values recorded in this experiment lie within the general range of $10^{-12}$ $10^{-8} \mathrm{~m}^{2} \mathrm{~s}^{-1}$ for drying of food materials.

\section{Effect of ultrasound on carrot flavour}

Untransformed maximum flavour response signals by nine $\mathrm{SNO}_{2}$ sensors of fresh, control, and ultrasonic pre-treated dried carrot cubes are shown in Figure 5A. It can be clearly seen that the flavour of the dried carrot in comparison with the fresh was degraded. However, compared with the flavour of the control, the ultrasound pre-treated sam-
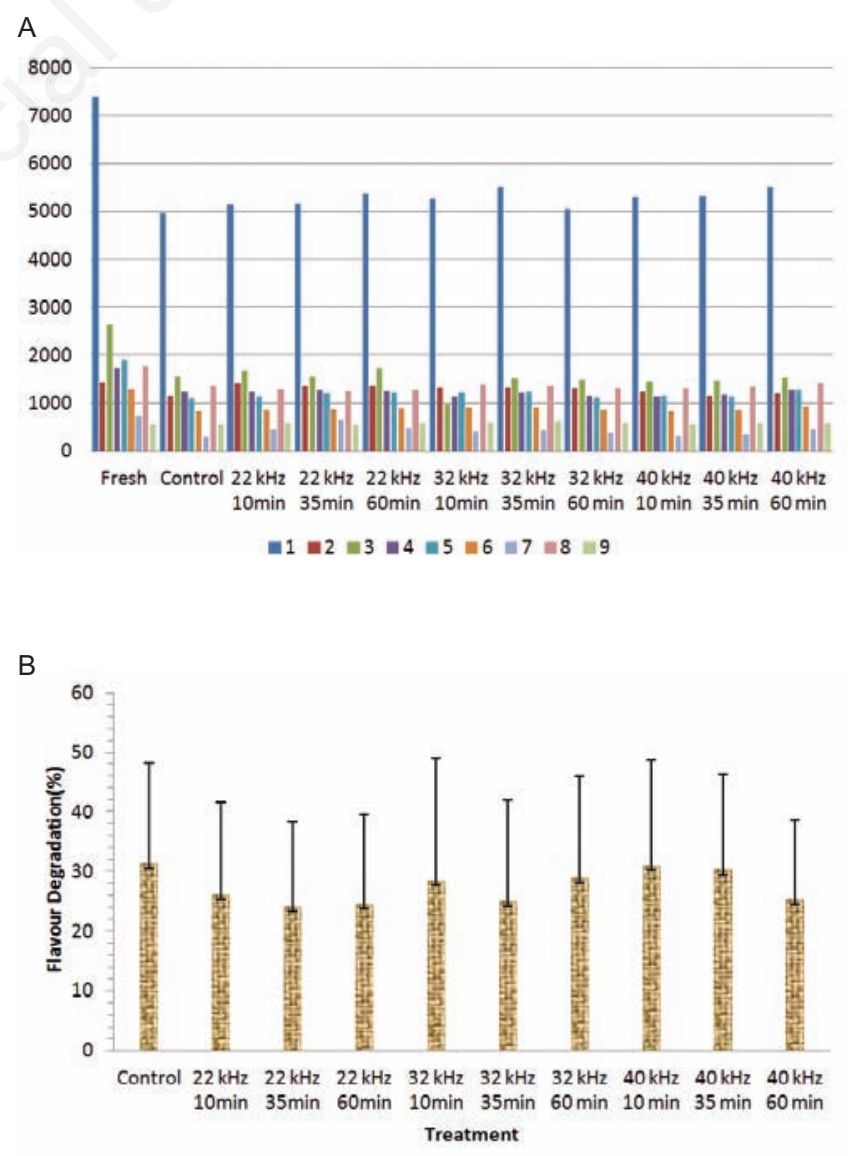

Figure 5. (A) Untransformed maximum flavour response signal by nine $\mathrm{SNO}_{2}$ of fresh, control, and ultrasonic pre-treated carrot; (B) Mean flavour degradation (\%) of nine $\mathrm{SNO}_{2}$ sensors of the control and the ultrasonic pre-treated dried carrot in comparison with the fresh. 
ples recorded higher flavour response signals. Thus, the application of ultrasound improved the flavour of the dried carrot. This is further supported by the mean flavour degradation response by the nine tin dioxide sensors (Figure 5B). The average flavour deterioration was $31.43 \%$ for the control samples whiles in the case of the ultrasound pre-treated samples, the degradation ranged between $24.38 \%$ and $30.39 \%$. The flavour of food is very important for its acceptability and a slight change in the flavour of processed food may affect the overall quality of the product. Degradation in flavour after dehydration has been reported. A distinct difference in flavour has been found in dried products compared to fresh ones as a result of heating (Hui and Clark, 2007). Lin et al. (1998) studied the flavour properties of vacuum-microwave-dried and air-dried carrot slices, which were first blanched in water. The vacuum-microwave-dried carrot slices received higher ratings for texture, flavour and overall acceptability as compared to the air-dried carrot slices, even though the flavour was degraded for both processing methods. Flavour degradation was also reported for tomato pomace dried at air temperatures of $50-90^{\circ} \mathrm{C}$ (Al-Muhtaseb, 2010). However, the tomato pomace dried at $50^{\circ} \mathrm{C}$ and $60^{\circ} \mathrm{C}$ were rated superior in flavour quality attributes to those dried at $80^{\circ} \mathrm{C}$ and $90^{\circ} \mathrm{C}$. The lower response signals by the electronic nose for the dried samples may be an indication that the associated enzymes responsible for producing the flavour of fresh carrots were inactivated as a result of heating in the control (Goodman et al., 2002) but the ultrasound pre-treatment improved the enzyme activity. The general degradation in flavour of the dried products agrees with previous reports by (Abano et al., 2012; Vadivambal and Jayas, 2007; Alibas et al, 2007; Contreras et al, 2008) for dried products.

\section{Effect of ultrasound on colour of dried carrot}

Colour change is another criterion for assessing the quality of dried products. The closer it is to the fresh carrot, the better consumers prefer it. Arslan and Özcan (2008) reported that higher values of brightness $\left(L^{*}\right)$ and ratio of redness to yellowness $\left(a^{*} / b^{*}\right)$ are desirable in dried carrot. Consumer preference studies of fresh carrot indicated that high $\mathrm{a}^{*}$ and $\mathrm{a}^{*} / \mathrm{b}^{*}$ values are preferred. On the above basis, the ultrasonic pretreated dried carrot at $24 \mathrm{~Hz}$ for 10 and 60 min would be preferred over the control ( $\mathrm{L}^{*}: 66.95, a^{*} / b^{*}: 0.556$ ) and others (Table 4). There was a statistical difference in the linear and quadratic effect of ultrasound frequency on the $L^{*}$ value of the dried samples (Table 5). The increase in ultrasound frequency improved the luminance of the dried products. Sonication time, however, did not statistically improve the brightness of the dried carrot. In addition, the increase in ultrasound frequency did not significantly decrease the $\mathrm{a}^{*} / b^{*}$ values. When the colour values of dried

Table 4. Three-level factorial design of ultrasound frequency and time and result of non-enzymatic browning index in absorbance units, brightness, and ratio of redness to yellowness.

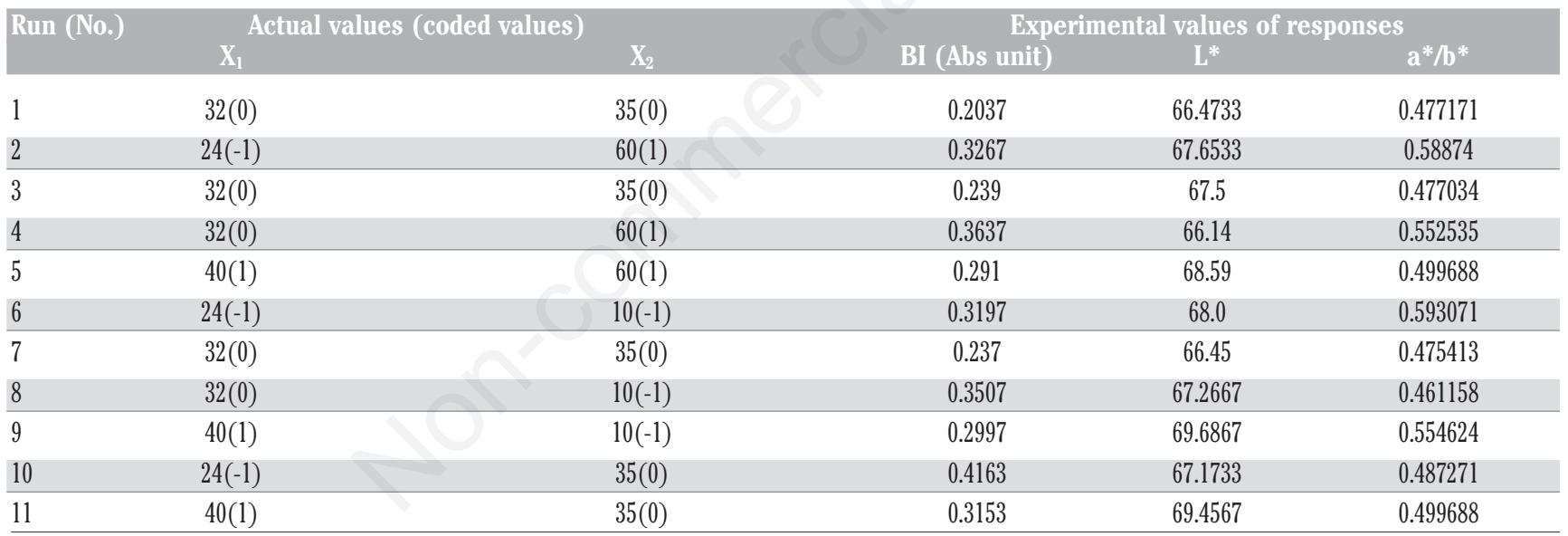

$\mathrm{X}_{1}$, ultrasound frequency; $\mathrm{X}_{2}$, time; $\mathrm{BI}$, non-enzymatic browning index; Abs, absorbance; $\mathrm{L}^{*}$, brightness; $\mathrm{a}^{*} / \mathrm{b}^{*}$, ratio of redness to yellowness.

Table 5. Analysis if variance (ANOVA) for the colour values by response surface quadratic model.

\begin{tabular}{|c|c|c|c|c|c|c|c|c|c|c|}
\hline \multirow[t]{2}{*}{ Source } & \multicolumn{2}{|c|}{ Coefficient estimate } & \multicolumn{2}{|c|}{ RSS } & \multirow[t]{2}{*}{ Df } & \multicolumn{3}{|c|}{ F value } & \multicolumn{2}{|c|}{ P Probability $>$ F } \\
\hline & $\mathbf{L}^{*}$ & $\mathbf{a} * / \mathbf{b} *$ & $L^{*}$ & $a * / b *$ & & $L^{*}$ & & $\mathbf{a}^{*} / \mathbf{b}^{*}$ & $\mathbf{L}^{*}$ & $\mathbf{a}^{*} / \mathbf{b} *$ \\
\hline Intercept $\left(\beta_{0}\right)$ & 66.75 & 0.47 & - & - & - & - & - & - & - & \\
\hline Model & - & 12.78 & 0.015 & 5 & 11.26 & 2.04 & & $0.0094^{*}$ & $0.2267^{* *}$ & \\
\hline$X_{I}\left(\beta_{1}\right)$ & 0.82 & -0.019 & 4.01 & 0.002207 & 1 & 17.67 & & 1.45 & $0.0085^{*}$ & $0.2821 * *$ \\
\hline$X_{2}\left(\beta_{2}\right)$ & -0.43 & 0.005352 & 1.10 & 0.0001719 & 1 & 4.85 & & 0.11 & $0.0789 * *$ & $0.7504^{* *}$ \\
\hline$X_{1} X_{2}\left(\beta_{3}\right)$ & -0.19 & -0.013 & 0.14 & 0.0006402 & 1 & 0.62 & & 0.42 & $0.4669 * *$ & $0.5450 * *$ \\
\hline$X_{1}^{2}\left(\beta_{4}\right)$ & 1.65 & 0.035 & 6.90 & 0.003191 & 1 & 30.39 & & 2.10 & $0.0027^{*}$ & $0.2071^{* *}$ \\
\hline$X_{2}^{2}\left(\beta_{5}\right)$ & 0.039 & 0.049 & 0.003794 & 0.006047 & 1 & 0.017 & & 3.98 & $0.9022 * *$ & $0.1027^{* *}$ \\
\hline Lack of fit & - & - & 0.42 & 0.0076 & 3 & 0.39 & & 2648.66 & $0.7781^{* *}$ & $0.0004^{*}$ \\
\hline$R^{2}$ & 0.9184 & 0.6708 & - & - & - & - & & - & - & - \\
\hline
\end{tabular}

RSS, sum of squares; Df, degree of freedom; $\mathrm{L}^{*}$, brightness; $\mathrm{a}^{*} / \mathrm{b}^{*}$, ratio of redness to yellowness. ${ }^{*}$ Significant; **not significant; at $\mathrm{P}>0.0$. 
carrots were compared with the fresh $\left(\mathrm{L}^{*}: 48.35, a^{*} / b^{*}: 0.641\right)$ there was enhancement in brightness and a general reduction in $a^{*} / b^{*}$. There was a significant difference in the colour of the control ( $\mathrm{L}^{*}: 66.95, a^{*} / b^{*}$ : 0.556 ) to the ultrasound pre-treated values (Table 4). Colour deterioration has been studied by several researchers for a number of products. Harbourne et al. (2009) reported that the drying method had a significant effect on the colour of meadowsweet extracts. Thermal processing and a non-enzymatic browning reaction was found to cause the colour changes in marigold which led to the destruction of pigments present in the petal (Wanyo et al., 2011). Prabhanjan et al. (1995) studied the thinlayer drying of carrot (Daucus carota) and showed that product dried by conventional air drying and microwave drying at half the power level retained good colour while those dried at maximum microwave power were dull. The colour of the final dried carrot may be strongly related to the beta-carotene in carrot that is known to possess enormous health benefits. The general decreasing trend of $a^{*} / b^{*}$ suggests less browning and may be the result of less Maillard reaction. The response surface plots of $L^{*}$ and $a^{*} / b^{*}$ for the dried tomato slices as well as their respective normal probability plots and simulated versus experimental plots are shown in Figures 6-11.

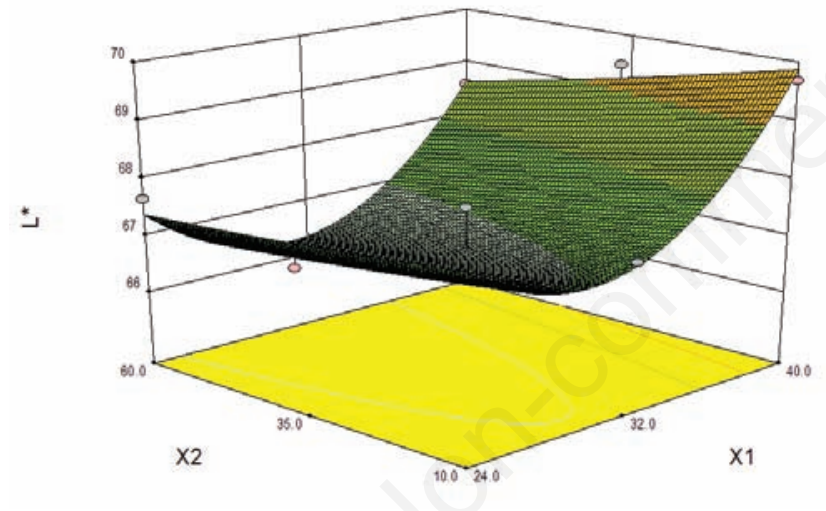

Figure 6. The effect of ultrasound frequency and time on the response surface plot of brightness $\left(\mathrm{L}^{*}\right)$ of dried carrot.

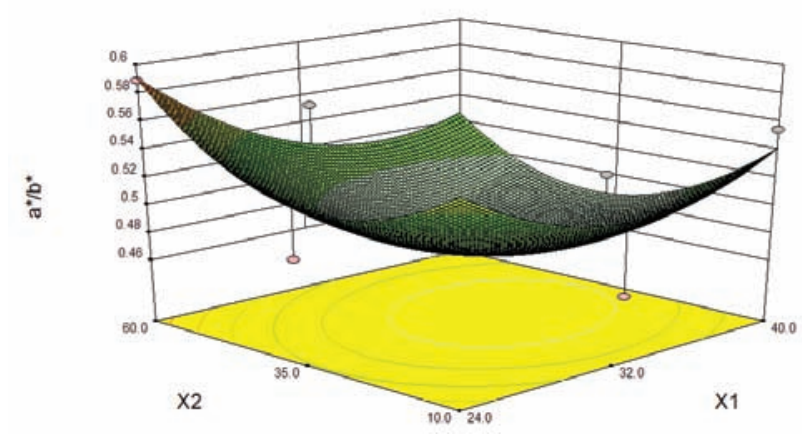

Figure 7. Effect of ultrasound frequency and time on the response surface plot of ratio of redness to yellowness $\left(\mathrm{a}^{*} / \mathrm{b}^{*}\right)$ of dried carrot.

\section{Effect of ultrasonic pre-treatment on browning index}

Non-enzymatic browning is another quality indicator in the drying of carrot. The extent of browning is mainly attributed to the colour changes resulting in Maillard reactions in the carrot (Zanoni et al., 1999). The response of the non-enzymatic browning index (BI) model and the ANOVA results (Table 6) clearly show that the ultrasound frequency and treatment time are insignificant model terms on the nonenzymatic browning of carrot cubes during drying. The application of

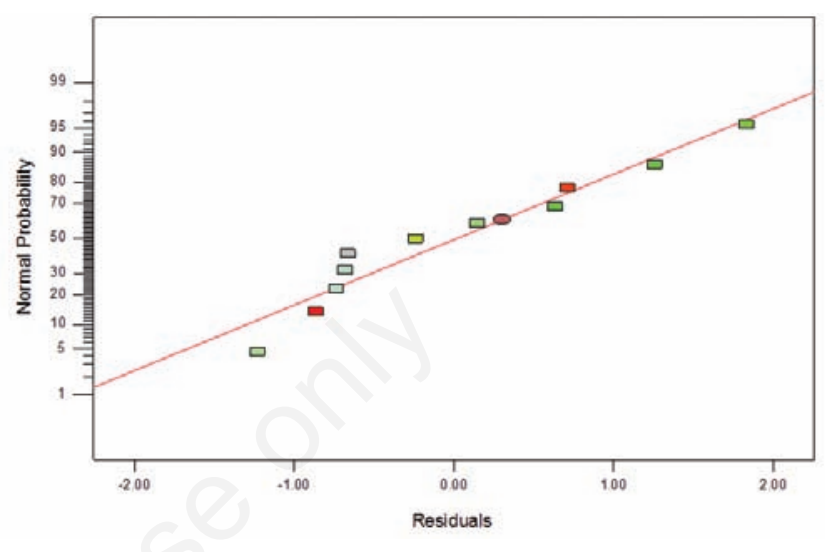

Figure 8. Normal probability plot of the brightness residuals.

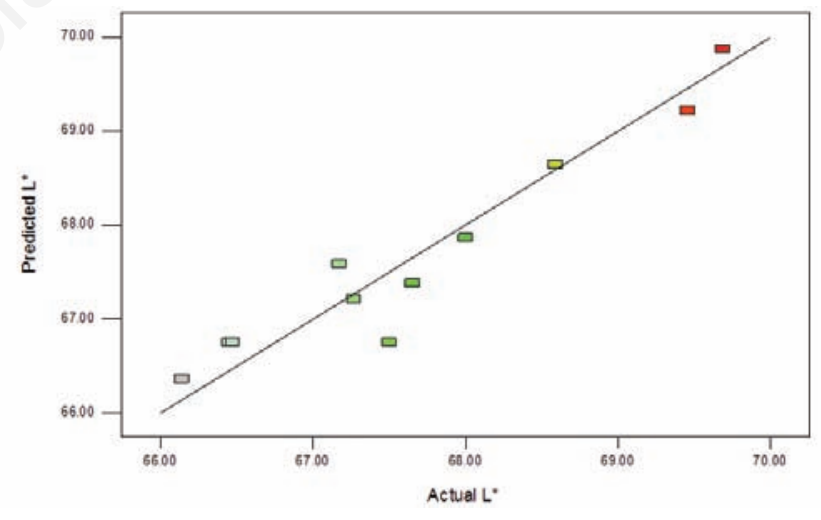

Figure 9. Predicted and simulated brightness $\left(\mathrm{L}^{*}\right)$ values.

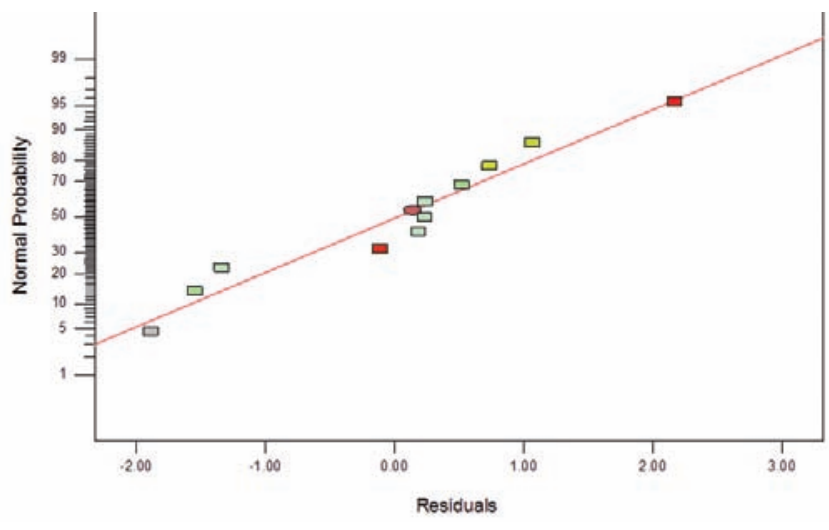

Figure 10. Normal probability plot of ratio of redness to yellowness residuals. 
the ultrasound reduced the BI values in comparison with that of the control (0.414). The reduction in BI values in the ultrasonic pre-treated died samples shows that the rate of brown pigment formation reduced with ultrasound application. Cernîşev (2010) dried tomato quarters at $50^{\circ} \mathrm{C}$ to $90^{\circ} \mathrm{C}$ and observed that the rate of browning increased with temperature from 0.585 to 0.684 . Browning index equal to 0.6 was considered critical based on comparison of visual assessment of the dried tomato samples and browning indexes of brown extracts. Browning during drying at lower temperatures $\left(<60^{\circ} \mathrm{C}\right)$ has been found to develop proportionally to temperature and follow a zero order reaction, whereas at higher temperatures $\left(>70^{\circ} \mathrm{C}\right)$ it showed a sharp rise.

Non-enzymatic browning is attributed to the occurrence of nitrogenous constituents and reducing sugars, nitrogenous constituents and organic acids, and sugars and organic acids in the carrot (Zanoni et al.,

Table 6. Analysis if variance (ANOVA) result for non-enzymatic browning for response surface quadratic model.

\begin{tabular}{lcccccc} 
Source & Coefficient estimate & RSS & Df & Mean square & F value & P Probability F \\
Model & - & 0.013 & 5 & 0.002684 & 0.54 & - \\
Intercept $\left(\beta_{0}\right)$ & 0.27 & - & - & - & $0.7411^{* *}$ \\
\hline$X_{1}\left(\beta_{1}\right)$ & -0.026 & 0.004092 & 1 & 0.004092 & 0.83 & $0.4050^{* *}$ \\
$X_{2}\left(\beta_{2}\right)$ & 0.001883 & 0.00002128 & 1 & 0.00002128 & 0.004298 & $0.9503^{* *}$ \\
\hline$X_{1} X_{2}\left(\beta_{3}\right)$ & -0.003925 & 0.00006162 & 1 & 0.00006162 & 0.012 & $0.9155^{* *}$ \\
$X_{1}^{2}\left(\beta_{4}\right)$ & 0.041 & 0.004202 & 1 & 0.004202 & 0.85 & $0.3992^{* *}$ \\
\hline$X_{2}^{2}\left(\beta_{5}\right)$ & 0.032 & 0.002615 & 1 & 0.002615 & 0.53 & $0.5000^{* *}$ \\
Lack of fit & - & 0.024 & 3 & 0.007990 & 20.32 & $0.0473^{*}$ \\
\hline$R^{2}$ & 0.3515 & - & - & - & - & -
\end{tabular}

RSS, sum of squares; Df, degree of freedom. *Significant; **not significant; at $\mathrm{P}>0.0$.

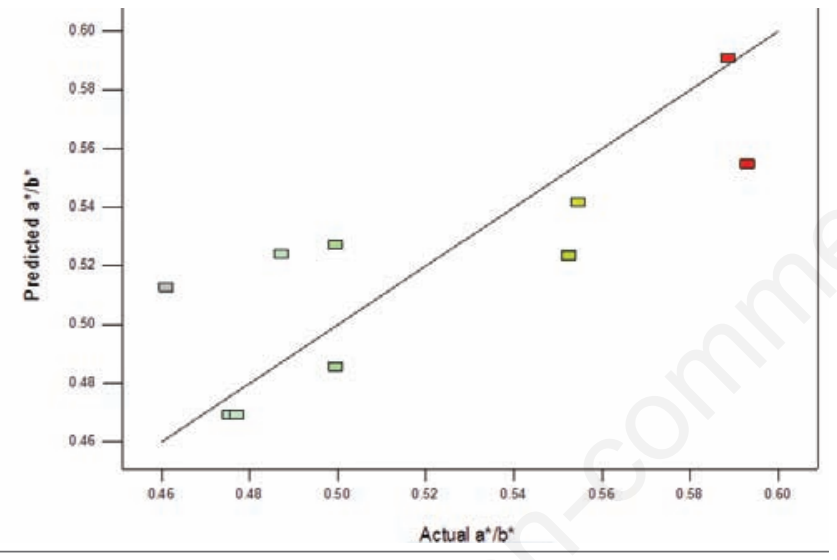

Figure 11. Predicted and simulated ratio of redness to yellowness $\left(\mathbf{a}^{*} / \mathbf{b}^{*}\right)$ values

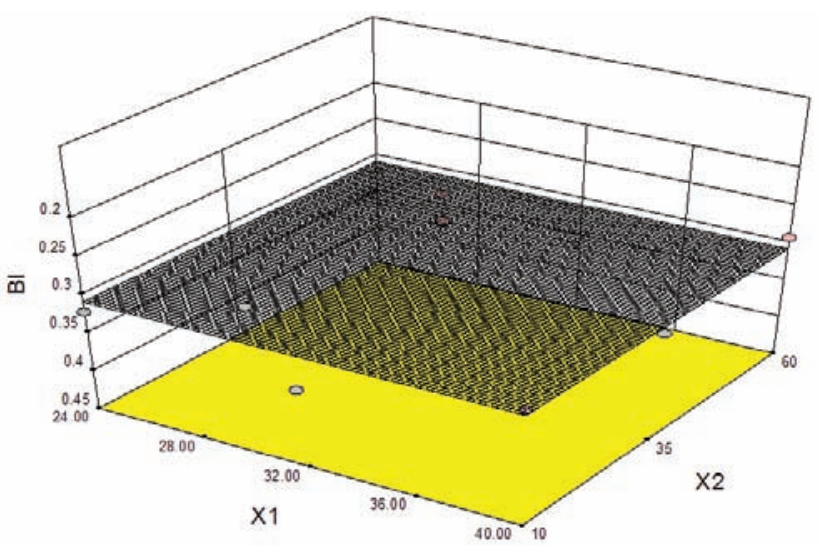

Figure 12. Effect of ultrasonic frequency and time on response surface plot of browning index (BI).

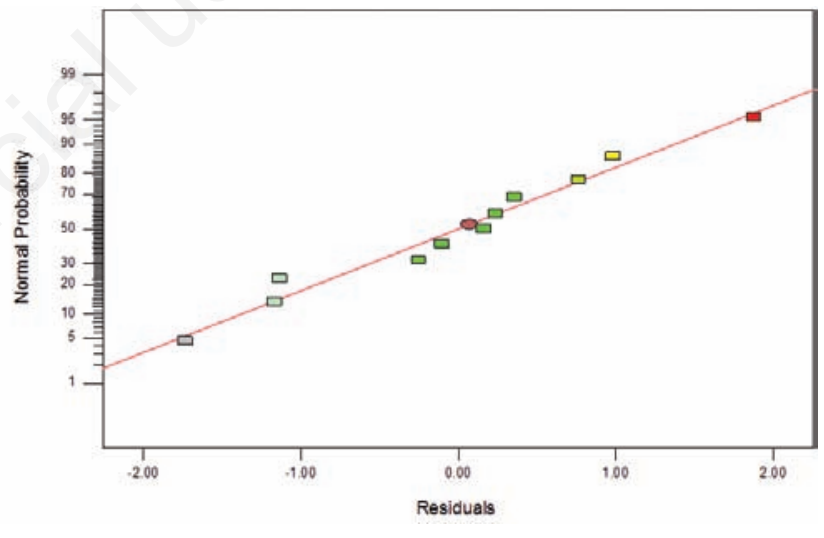

Figure 13. Normal probability plot of the browning index residuals.

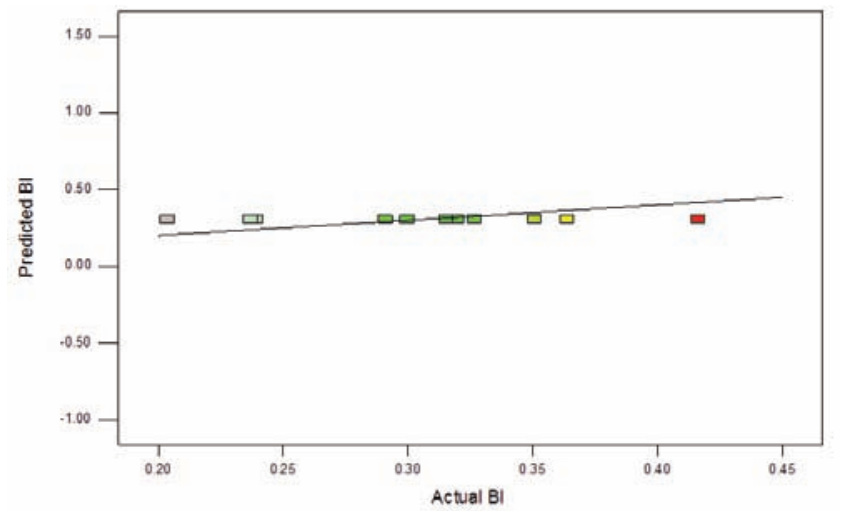

Figure 14. Predicted and simulated browning index (BI) values. 
1999; Muratore, 2008; Cernîşev, 2010). In this study, ultrasonic pretreatment resulted in sugar loss and this may have reduced the BI in these samples. The effect of ultrasound frequency and sonication time on the formation of brown pigments of dried carrot by the response surface plots is shown in Figure 12. The plots of the normal probability of the residuals together with the predicted and actual non-enzymatic browning indexes are shown in Figures 13 and 14. The statistical result in Table 6 shows that the overall mean is a better predictor of $\mathrm{BI}$ than the quadratic model.

\section{Conclusions}

It was shown that the use of ultrasonic pre-treatment affected the water loss and sugar gain of carrot during pre-treatment and the water diffusivity of carrot during the air-drying process. The application of ultrasound caused the removal of soluble solids from the carrots, which led to the production of carrots with low sugar content. The water diffusivity increased by $30.47 \%, 41.79 \%$, and $44.92 \%$ after subjecting the carrots to $32 \mathrm{kHz}$ ultrasound for 10,35 and $60 \mathrm{~min}$, respectively. The flavour response signals for samples submitted to ultrasound were higher than the samples without ultrasonic pre-treatment. The increase in ultrasound frequency improved the luminance of the dried products. However, sonication time did not statistically improve the brightness of the dried carrot. The use of the ultrasound in carrot processing improved the nonenzymatic browning even though variation of ultrasound frequency and time did not significantly reduce browning.

\section{References}

Abano E.E., Ma H., Qu W. 2011. Influence of air temperature on the drying kinetics and quality of tomato slices. J. Food Process. Technol. 2:1-9.

Abano E.E., Ma H., Qu W. 2012. Influence of combined microwave-vacuum drying on drying kinetics and quality of dried tomato slices. J. Food Quality. 35:159-68.

Abano E.E., Sam-Amoah L.K. 2011. Effects of different pretreatments on drying characteristics of banana slices. J. Eng. Applied Sci. 6:121-9.

Alibas Ozkan I., Akbudak B., Akbudak N. 2007. Microwave drying characteristics of spinach. J. Food Eng. 78:577-83.

Al-Muhtaseb A.H., Al-Harahsheh M., Hararah M., Magee T.R.A. 2010. Drying characterisitics and quality change of unutilized-protein rich tomato pomace with and without osmotoic pre-treatment. J. Industr. Crops Prod. 31:171-7.

Antonio G.C., Alves D.G., Azoubel P.M., Murr F.E.X., Park K.J. 2008. Influence of osmotic dehydration and high temperature short time processes on dried sweet potato (Ipomoea batatas Lam.). J. Food Eng. 84:375-82.

Arslan D., Özcan M.M. 2008. Evaluation of drying methods with respect to drying kinetics, mineral content, and colour characteristics of rosemary leaves. Energy Convers. Manage. 49:1258-64.

Azoubel P.M., Baima M.A., Amorim M.R., Oliveira S.S.B. 2010. Effect of ultrasound on banana Cv Pacovan drying kinetics. J. Food Eng. 97:194-8.

Azoubel P.M., El-Aouar A.A., Tonon R.V., Kurozawa L.E., Antonio G.C., Murr F.E.X., Park K.J. 2009. Effect of osmotic dehydration on the drying kinetics and quality of cashew apple. Intern J. Food Sci. Technol. 44:980-6.

Azzouz S., Guizani A., Jomaa W., Belghith A. 2002. Moisture diffusivity and drying kinetic equation of convective drying of grapes. J. Food
Eng. 55:323-30.

Cárcel J.A., Garcia-Perez J.V., Riera E., Mulet A. 2011. Improvement of convective drying of carrot by applying power ultrasound. Influence of mass load density. Dry Technol. 29:174-82.

Cernîşev S. 2010. Effects of conventional and multistage drying processing on non-enzymatic browning in tomato. J. Food Eng. 96:114 8.

Contreras C., Martin M.E., Martínez-Navarrete N., Chiralt A. 2008. Influence of microwave application on drying kinetics, and optical mechanical properties of apple and strawberry. J. Food Eng. 88:55 64.

De la Fuente S., Riera E., Acosta V.M., Blanco A., Gallego-Juárez J.A. 2006. Food drying process by power ultrasound. Ultrasonics 44:e523-7.

FA0. 2010. Faostat data base query. Available from: http://www.fao.org Accessed: 14 July 2012.

Fernandes F.A.N., Gallão M.I., Rodrigues S. 2008b. Effect of osmotic dehydration and ultrasound pre-treatment on cell structure: melon dehydration. Food Sci. Technol. 41:604-10.

Fernandes F.A.N., Gallão M.I., Rodrigues, S. 2009. Effect of osmosis and ultrasound on pineapple cell tissue structure during dehydration. J. Food Eng. 99:186-90.

Fernandes F.A.N., Linhares Jr F.E., Rodrigues S. 2008a. Ultrasound as pretreatment for drying of pineapple. Ultrasonics Sonochem. 15:1049-54.

Fernandes F.A.N., Rodrigues S. 2007. Ultrasound as pre-treatment for drying of fruits: dehydration of banana. J. Food Eng. 82:261-7.

Fuente-Blanco S., Sarabia E.R.F., Acosta-Aparicio V.M., Blanco-Blanco A., Gallego-Juárez J.A. 2006. Food drying process by power ultrasound. Ultrasonics Sonochem. 44:e523-7.

Goodman C., Fawcett S., Barringer S.A. 2002. Flavour, viscosity, and colour analysis of hot and cold break tomato juices. J. Food Sci. 67:404-8.

Harbourne N., Marete E., Jacquier J.C., O'Riordan D. 2009. Effect of drying methods on the phenolic constituents of meadowsweet (Filipendula ulmaria) and willow (Salix alba). Food Sci. Technol. 42:1468-73.

Hui Y.H., Clark S. 2007. Quality of dried tomatoes. In: Y.H. Hui (ed.) Handbook of food products manufacturing, Marcel Dekker, Inc., New York, NY, USA. pp 623-626.

Jambrak A.R., Mason T.J., Paniwnyk L., Lelas V. 2007. Accelerated drying of button mushrooms, Brussels sprouts and cauliflower by applying power ultrasound and its rehydration properties. J. Food Eng. 81:88-97.

Karim M.A., Hawlader M.N.A. 2005. Drying characteristics of banana: theoretical modeling and experimental validation. J. Food Eng. 70:100-06.

Lin T.M., Durance T.D., Scaman C.H. 1998. Characterization of vacuum microwave, air and freeze dried carrot slices. Food Res. Intern. 31:111-7.

Lombard G.E., Oliveira J.C., Fito P., Andrés A. 2008. Osmotic dehydration of pineapple as a pre-treatment for further drying. J. Food Eng. 85:277-84.

Mason T.J. 1998. Power ultrasound in food processing - the way forward. In: Povey M.J.W., Mason T.J., eds. Ultrasounds in food processing. Blackie Academic and Professional, Glasgow, UK. pp 104124.

Mujumdar A.S., Menon A.S. 1995. Drying of solids: principles, classification, and selection of dryers. In: Mujumdar A.S., ed. Handbook of industrial drying, vol. 1. Marcel Dekker, New York, NY, USA. pp 139.

Muralidhara H.S., Ensminger D., Putnam A. 1985. Acoustic dewatering and drying (low and high frequency): State of the art review. Dry 
Technol. 3:529-66.

Muratore G., Rizzo V., Licciardello F., Maccarone E. 2008. Partial dehydration of cherry tomato at different temperature, and nutritional quality of the products. Food Chem. 111:887-91.

Nguyen M.H., Price W.E. 2007. Air-drying of banana: influence of experimental parameters, slab thickness, banana maturity and harvesting season. J. Food Eng. 79:200-7.

Page G.E., 1949. Factors influencing the maximum rates of air drying shelled corn in thin layers. M.Sc. Thesis. Purdue University, IN, USA.

Pani P., Leva A.A., Riva M., Maestrelli A., Torreggiani D., 2008. Influence of an osmotic pre-treatment on structure property relationships of air dehydrated tomato slices. J. Food Eng. 86:105-12.

Perry R.H., Green D.W. 1999. Chemical engineers handbook. McGrawHill, New York, NY, USA.

Prabhanjan D.G., Ramaswamy H.S., Raghavan G.S.V. 1995. Microwave assisted convective air drying of thin layer carrots. J. Food Eng. 25:283-93.

Simal S., Femenia A., Garau M.C., Rosselló C., 2005. Use of exponential, Page's and diffusional models to simulate the drying kinetics of kiwi fruit. J. Food Eng. 66:323-8.

Vadivambal R., Jayas D.S. 2007. Changes in quality of microwave-treated agricultural products- a review. J. Biosyst. Eng. 98:1-16.

Wanyo P., Siriamornpun S., Meeso N. 2011. Improvement of quality and antioxidant properties of dried mulberry leaves with combined farinfrared radiation and air convection in Thai tea process. Food Bioprod. Proc. 89:22-30.

Xiaobo Z., Jiewen Z. 2008. Comparative analyses of apple aroma by a tin-oxide gas sensor array device and GC/MS. J. Food Chem. 107:120-8.

Zanoni B., Peri C., Nani R., Lavelli, V. 1999. Oxidative heat damage of tomato halves as affected by drying. Food Res. Intern. 31:395-401. 